\title{
Perbandingan Penyembuhan Luka Insisi Menggunakan Pisau Bedah dan Pisau Elektrokauter Dinilai dengan Vancouver scar score pada Operasi Luka Bersih
}

\author{
${ }^{1}$ Diadon Mitaart, ${ }^{2}$ Mendy Hatibie, ${ }^{3}$ Djarot Noersasongko
}

\author{
${ }^{1}$ Program Studi Ilmu Bedah Fakultas Kedokteran Universitas Sam Ratulangi Manado \\ ${ }^{2}$ KSM Ilmu Bedah Divisi Bedah Plastik RSUP Prof. Dr. R. D. Kandou Manado \\ ${ }^{2}$ KSM Ilmu Bedah Divisi Bedah Ortopedi RSUP Prof. Dr. R. D. Kandou Manado \\ Email: donmitaart@gmail.com
}

\begin{abstract}
Skin incision is usually performed by using a scalpel. It is assumed that electrocautery knife, a more recent alternative, can increase the risk of infection, impair healing, and result in poor cosmetic scar. This study was aimed to compare the healing process of incision wounds performed by using sclapels and electrocautery knives assessed with Vancouver Scar Score (VSS) at three months after operation. This was an experimental study. Subjects were 17 male patients, aged 18-55 years old, with elective operation (categorized as clean wound operation) from March through June 2016 at Prof. Dr. R. D. Kandou Hospital Manado. Each incision was performed with a scalpel first (Group A) and continued with an electrocautery knife (Group B). After 3 months of operation, the wound scars were assessed with VSS. The Wilcoxon signed ranks test showed no significant difference between the VSS of the two groups $(P>0.05)$. Conclusion: There was no difference in wound healing of incised wounds performed by using scalpels and by using electrocautery knives.
\end{abstract}

Keywords: VSS, electrocautery, wound healing, scar

\begin{abstract}
Abstrak: Insisi kulit biasanya dilakukan dengan menggunakan pisau bedah. Peralatan elektrokauter merupakan alternatif baru yang dianggap meningkatkan risiko infeksi, memperlambat penyembuhan, dengan hasil secara kosmetik yang buruk. Penelitian ini bertujuan untuk membandingkan proses penyembuhan dari luka insisi menggunakan pisau bedah dan pisau elektrokauter yang dinilai dengan Vancouver Scar Score (VSS) pada operasi dengan luka bersih. Jenis penelitian ialah eksperimental. Penelitian dilakukan selama periode Maret 2016 s/d Juni 2016 pada 17 orang pasien berjenis kelamin laki-laki, berusia 18-55 tahun yang memerlukan operasi elektif di RSUP Prof. Dr. R. D. Kandou Manado dan dikategorikan operasi dengan luka bersih. Setiap insisi selalu dilakukan terlebih dahulu dengan pisau bedah (kelompok A) dan sisanya dilakukan dengan pisau elektrokauter (kelompok B), kemudian luka dinilai dengan VSS setelah 3 bulan kemudian. Hasil uji Wilcoxon signed ranks terhadap hasil VSS saat 3 bulan setelah operasi memperlihatkan tidak terdapat perbedaan bermakna antara hasil perlakuan A dan B $(P>0,05)$. Simpulan: Tidak terdapat perbedaan dalam penyembuhan dari kedua bagian luka insisi yang menggunakan pisau bedah dan pisau elektrokauter pada operasi dengan luka bersih.
\end{abstract}

Kata kunci: VSS, elektrokauter, penyembuhan luka, jaringan parut

Jaringan parut (skar) terbentuk setelah prosedur bedah dan berbagai jenis trauma, terutama luka bakar. Beberapa bekas luka sembuh dengan cepat, sementara yang lain berkembang menjadi skar hipertrofik atau bahkan keloid. Bekas luka sering memerlukan perawatan selama berbulanbulan atau bahkan beberapa tahun. ${ }^{1}$

Jaringan parut dapat menyebabkan berbagai masalah, antara lain masalah 
kosmetik, psikologis, dan masalah fungsional. Jaringan parut biasanya dibedakan dari kulit normal dari segi perbedaan warna, peningkatan ketebalan, luas permukaan yang tidak rata, dan kualitas fungsional yang jelek, disebabkan oleh hilangnya kelenturan dan kontraksi. Gambaran jaringan parut secara klinis relevan dan berhubungan dengan kualitas dan penilaian jaringan parut. Untuk evaluasi hasil uji klinis, baik pengukuran subjektif maupun objektif dari jaringan parut sangat diperlukan. ${ }^{1}$

Penilaian jaringan parut diperlukan dalam praktek klinis di pusat-pusat yang mengobati korban luka bakar dan pasien lain dengan bekas luka yang bermasalah. Untuk saat ini metode yang diketahui untuk menilai jaringan parut masih jarang. Dalam studi ilmiah tentang jaringan parut, penilaian skoring Vancouver Scar Score (VSS) yang paling umum digunakan. Meskipun pernah dilaporkan bahwa penilaian subjektif tidak terlalu dapat diandalkan namun VSS telah menjadi baku emas untuk menilai jaringan parut. ${ }^{2}$

Penggunaan dan pengetahuan mengenai prosedur bedah listrik sangat penting dalam bidang bedah kulit. Bedah listrik merupakan suatu teknik bedah yang menggunakan transmisi listrik untuk memotong jaringan, menghancurkan jaringan, dan mengkauterisasi pembuluh darah. Panjang gelombang arus listrik yang bervariasi dapat menyebabkan efek biologis yang berbeda pada jaringan. Bedah listrik dalam bidang dermatologi mencakup beberapa modalitas terapi, yaitu elektrofulgurasi, elektrodesikasi, elektrokoagulasi, elektroseksi, elektrokauterisasi, dan elektrolisis. ${ }^{3,4}$ Elektrokauterisasi sendiri bukan merupakan modalitas bedah listrik murni karena tidak ada aliran listrik yang melalui tubuh pasien. ${ }^{5}$

Bedah elektrokauter telah berkembang pesat, dan digunakan untuk pemisahan jaringan serta hemostasis. Bedah elektrokauter merupakan metode yang praktis, awalnya diperkenalkan pada abad ke-20 namun ternyata dokter bedah masih agak segan menggunakannya bila tujuannya untuk insisi kulit. Hal ini disebabkan karena laporan penelitian sebelumnya yang menunjukkan bahwa elektrokauter menyebabkan pertumbuhan jaringan yang buruk yang bisa berujung pada infeksi jaringan, keterlambatan penyembuhan, dan pertumbuhan jaringan parut yang buruk. Walaupun laporan hasil penelitian tersebut kurang menjanjikan, penelitian mengenai pengaruh elektrokauter terhadap luka seperti durasi operasi dan perdarahan juga termasuk infeksi pada luka operasi masih cukup diminati. ${ }^{6}$ Beberapa penelitian telah dilakukan untuk membandingkan hasil insisi yang dilakukan dengan menggunakan pisau bedah dan peralatan elektrokauter serta menilai hasil dari penyembuhan luka, keefektifan, kurangnya perdarahan yang dihasilkan, dan kepuasan pasien pasca operasi. Laporan berbagai hasil penelitian tersebut memperlihatkan penggunaan peralatan elektrokauter sama amannya dengan pisau bedah dalam hal penyembuhan luka insisi dengan beberapa keuntungan tambahan antara lain berkurangnya kehilangan darah dan nyeri pasca operasi. ${ }^{7-10}$

\section{METODE PENELITIAN}

Jenis penelitian ini ialah ekperimental. Penelitian dilakukan selama periode Maret 2016 s/d Juni 2016 terhadap pasien yang datang dan memerlukan operasi elektif di RSUP Prof. Dr. R. D. Kandou Manado, kategori operasi dengan luka bersih, berjenis kelamin laki-laki, dan berusia 1855 tahun.

Tahapan perlakuan yang diberikan ialah sebagai berikut: Pada lokasi operasi diberi tanda insisi (marker), setengahnya diinsisi dengan pisau bedah (sebelah proksimal/lateral) dan setengahnya lagi diinsisi dengan pisau elektrokauter (sebelah distal/medial). Setelah dilakukan tindakan asepsis dan antisepsis, dibuat insisi kulit dengan menggunakan pisau bedah mengikuti marker sampai pada lapisan lemak subkutan. Insisi kulit diteruskan menggunakan pisau elektrokauter sampai lapisan subkutis, sebelumnya telah diatur pure cut mode dan angka 20 watt pada 
mesin kauter. Insisi dilakukan dengan kecepatan 3-5 cm per detik dengan sekali insisi mengikuti marker. Luka dijahit dengan jahitan interuptus menggunakan benang monofilamen non-absorable ukuran 2-0 untuk ekstremitas dan 3-0 untuk trunkus. Setelah luka ditutup, dilakukan pendokumentasian. Perawatan luka dilakukan seperti biasanya dan luka dinilai dengan VSS saat 3 bulan setelah operasi.

Hasil penilaian VSS pada luka insisi dengan pisau bedah dimasukkan dalam kelompok A sedangkan yang dengan pisau elektrokauter dimasukkan dalam kelompok B. Penilaian pada bekas luka memakai standar baku yaitu VSS, terdiri dari: konsistensi (0-5 poin), ketebalan (0-3 poin), vaskularisasi (0-3 poin), dan pigmentasi (03 poin) (Tabel 1$).^{2}$

Analisis data dilakukan secara deskriptif dan analisis perbandingan kedua perlakuan menggunakan uji Wilcoxon signed ranks.

Tabel 1. Vancouver Scar Score ${ }^{2}$

\begin{tabular}{llc}
\hline \multicolumn{2}{c}{ Karakteristik skar } & Skor \\
\hline Vaskularisasi & Normal & 0 \\
& Merah muda & 1 \\
& Merah & 2 \\
& Ungu & 3 \\
Pigmentasi & Normal & 0 \\
& Hipopigmentasi & 1 \\
& Campuran & 2 \\
& Hiperpigmentasi & 3 \\
Konsistensi & Normal & 0 \\
& Lentur & 1 \\
& Lunak & 2 \\
& Keras & 3 \\
& Padat & 4 \\
& Kontraktur & 5 \\
Ketinggian/ & Datar & 0 \\
ketebalan & & \\
& $<2 \mathrm{~mm}$ & 1 \\
& $2-5 \mathrm{~mm}$ & 2 \\
Total skor & $>5 \mathrm{~mm}$ & 3 \\
\hline
\end{tabular}

\section{HASIL PENELITIAN}

Subyek penelitian diperoleh dari pasien yang dilakukan operasi dengan kategori operasi luka bersih di RSUP Prof. Dr. R. D. Kandou Manado. Penelitian ini dilakukan pada 17 luka operasi. Sebanyak 14 luka didapatkan dari operasi Divisi Ortopedi dan 3 luka dari operasi Divisi Digestif (Tabel 2 dan 3). Insisi awal selalu dimulai dengan pisau bedah sepanjang $1 / 2$ dari panjang insisi luka dan kemudian sisanya diperpanjang dengan menggunakan pisau elektrokauter yang sebelumnya sudah diatur ke pure cut mode dan angka 20 watt pada mesin kauter. Selanjutnya luka mendapat perlakuan perawatan luka yang sama, dan dikontrol setelah 3 bulan kemudian, dan dinilai dengan menggunakan VSS.

Tabel 2 memperlihatkan hasil penilaian luka dengan VSS pada kelompok A (insisi dengan pisau bedah) sedangkan Tabel 3 memperlihatkan hasil penilaian dengan VSS pada kelompok B (insisi dengan pisau elektrokauter).

\section{Analisis data}

Hasil uji kenormalan data menunjukkan bahwa data konsistensi dan ketebalan pada perlakuan A dan B tidak menyebar normal $(P<0,05)$ sehingga perbedaan kedua perlakuan diuji dengan Wilcoxon signed ranks yang menunjukkan tidak terdapat perbedaan bermakna dalam konsistensi $(P>0,05)$ dan ketebalan antara perlakuan A dan B $(P>0,05)$.

Hasil uji kenormalan data menunjukkan data vaskularisasi dan pigmentasi perlakuan A dan B tidak menyebar normal $(P<0,05)$ sehingga perbedaan kedua perlakuan diuji dengan Wilcoxon signed ranks yang menyatakan tidak terdapat perbedaan dalam vaskularisasi $(P<0,05)$ dan pigmentasi antara perlakuan $\mathrm{A}$ dan $\mathrm{B}$ $(P>0,05)$.

Hasil uji kenormalan data menunjukkan data hasil perlakuan $\mathrm{A}$ dan B tidak menyebar normal $(P<0,05)$ maka perbedaan kedua perlakuan diuji dengan Wilcoxon signed ranks yang menunjukkan tidak terdapat perbedaan bermakna antara hasil perlakuan A dan B $(P>0,05)$. 
Tabel 1. Hasil penilaian dengan VSS pada kelompok A (insisi dengan pisau bedah)

\begin{tabular}{lllllllll}
\hline $\begin{array}{c}\text { Sampel } \\
\text { luka }\end{array}$ & Usia & \multicolumn{1}{c}{ Regio } & Jenis operasi & I & II & III & IV & Hasil \\
\hline Luka 1 & 28 & SIAS & K Nail femur & 1 & 2 & 0 & 1 & 4 \\
Luka 2 & 28 & Femoral & K Nail femur & 1 & 1 & 1 & 1 & 4 \\
Luka 3 & 28 & Femoral & K Nail femur & 1 & 2 & 0 & 0 & 3 \\
Luka 4 & 45 & Patela & ORIF & 0 & 1 & 2 & 0 & 3 \\
Luka 5 & 45 & Femoral & ORIF & 0 & 1 & 1 & 1 & 3 \\
Luka 6 & 18 & Humerus & ORIF & 1 & 0 & 2 & 0 & 3 \\
Luka 7 & 35 & Femoral & ORIF & 1 & 2 & 1 & 0 & 4 \\
Luka 8 & 38 & Vertebra & Laminectomy & 0 & 1 & 1 & 1 & 3 \\
Luka 9 & 50 & Ingunal & Herniotomy & 1 & 1 & 0 & 0 & 2 \\
Luka 10 & 43 & Antebrachi & ORIF & 1 & 2 & 1 & 1 & 5 \\
Luka 11 & 43 & Antebrachi & ORIF & 0 & 1 & 0 & 2 & 3 \\
Luka 12 & 42 & Vertebra & Laminectomy & 0 & 1 & 0 & 1 & 2 \\
Luka 13 & 55 & Inguinal & Herniotomy & 1 & 0 & 1 & 1 & 3 \\
Luka 14 & 40 & Femoral & ORIF & 1 & 1 & 0 & 1 & 3 \\
Luka 15 & 40 & Femoral & ORIF & 0 & 1 & 1 & 1 & 3 \\
Luka 16 & 18 & Clavicula & ORIF & 1 & 0 & 1 & 0 & 2 \\
Luka 17 & 43 & Mid line abdomen & Cholecystectomy & 5 & 2 & 3 & 2 & 12 \\
\hline
\end{tabular}

Tabel 2. Hasil penilaian dengan VSS pada kelompok B (insisi dengan pisau elektrokauter)

\begin{tabular}{|c|c|c|c|c|c|c|c|c|}
\hline $\begin{array}{c}\text { Sampel } \\
\text { luka }\end{array}$ & Usia & Regio & Jenis operasi & $\mathbf{I}$ & II & III & IV & Hasil \\
\hline Luka 1 & 28 & SIAS & K Nail femur & 1 & 2 & 0 & 1 & 4 \\
\hline Luka 2 & 28 & Femoral & K Nail femur & 1 & 1 & 1 & 1 & 4 \\
\hline Luka 3 & 28 & Femoral & K Nail femur & 1 & 2 & 0 & 0 & 3 \\
\hline Luka 4 & 45 & Patela & ORIF & 0 & 1 & 2 & 0 & 3 \\
\hline Luka 5 & 45 & Femoral & ORIF & 0 & 1 & 1 & 1 & 3 \\
\hline Luka 6 & 18 & Humerus & ORIF & 1 & 0 & 2 & 0 & 3 \\
\hline Luka 7 & 35 & Femoral & ORIF & 1 & 2 & 1 & 0 & 4 \\
\hline Luka 8 & 38 & Vertebra & Laminectomy & 0 & 1 & 1 & 1 & 3 \\
\hline Luka 9 & 50 & Ingunal & Herniotomy & 1 & 1 & 0 & 0 & 2 \\
\hline Luka 10 & 43 & Antebrachi & ORIF & 1 & 2 & 1 & 1 & 5 \\
\hline Luka 11 & 43 & Antebrachi & ORIF & 0 & 1 & 0 & 2 & 3 \\
\hline Luka 12 & 42 & Vertebra & Laminectomy & 0 & 1 & 0 & 1 & 2 \\
\hline Luka 13 & 55 & Inguinal & Herniotomy & 1 & 0 & 1 & 1 & 3 \\
\hline Luka 14 & 40 & Femoral & ORIF & 1 & 1 & 0 & 1 & 3 \\
\hline Luka 15 & 40 & Femoral & ORIF & 0 & 1 & 1 & 1 & 3 \\
\hline Luka 16 & 18 & Clavicula & ORIF & 1 & 0 & 1 & 0 & 2 \\
\hline Luka 17 & 43 & Mid line abdomen & Cholecystectomy & 5 & 2 & 3 & 2 & 12 \\
\hline
\end{tabular}

Keterangan: I, Konsistensi (0 - 5); II, Ketebalan (0 - 3); III: Vaskularisasi (0 - 3); IV: Pigmentasi (0 - 3)

\section{BAHASAN}

Respon fisiologik pada luka ialah proses penyembuhan luka. Pemahaman terhadap proses penyembuhan luka secara normal merupakan hal penting dalam pemahaman patofisiologi jaringan parut atau keloid. Penyembuhan luka merupakan proses sangat kompleks dan secara normal terjadi melalui tiga fase yaitu: 1) fase inflamasi; 2) fase proliferasi; dan 3) fase remodeling. ${ }^{11}$ Penyembuhan luka sering berakhir dengan meninggalkan jaringan parut. Walaupun jaringan parut terdiri dari protein yang sama (kolagen) dengan jaringan yang digantikannya, namun komposisi serat proteinnya yang berbeda, 
yaitu bukannya membentuk anyaman acak dari serat kolagen seperti yang ditemukan pada jaringan normal melainkan membentuk anyaman satu arah pada jaringan parut. Barisan kolagen dari jaringan parut ini mempunyai kualitas fungsional yang lebih buruk dari pada kolagen yang teranyam acak. Contohnya, jaringan parut pada kulit lebih kurang tahan terhadap radiasi ultraviolet, lagipula kelenjar keringat serta folikel rambutnya tidak tumbuh lagi bersama dengan jaringan parut. $^{12,13}$

Jaringan parut adalah suatu area jaringan fibrosis yang menggantikan kulit normal setelah cedera yang bertujuan untuk memperbaiki luka pada kulit maupun pada organ lain dari tubuh. Dengan demikian, proses pembentukan jaringan parut merupakan bagian dari proses penyembuhan yang alami. Dengan pengecualian dari lesi yang sangat kecil, setiap luka (setelah trauma, penyakit, atau tindakan bedah) menghasilkan hasil jaringan parut yang berbeda derajat. ${ }^{12,13}$

Jaringan parut yang terbentuk dapat dibedakan atas skar hipertrofik dan keloid. Skar hipertrofik merupakan tipe jaringan parut yang terbatas pada defek awal dan cenderung menghilang seiring waktu sedangkan keloid ialah perluasan skar yang melewati batas luka awal. ${ }^{14,15}$ Konsep ini menyatakan pula bahwa suatu skar dapat berawal sebagai skar hipertrofi, kemudian menjadi keloid bila melewati batas luka. ${ }^{15}$

Beberapa modalitas telah dirancang untuk mengukur bekas luka dengan tujuan menentukan respon terhadap pengobatan dan untuk mengevaluasi hasil. Penilaian jaringan parut bisa dilakukan secara obyektif atau subyektif. Penilaian obyektif memberikan pengukuran kuantitas jaringan parut, sedangkan penilaian subyektif tergantung pengamat. Penilaian kuantitatif jaringan parut membutuhkan perangkat untuk mengukur fisik sedangkan penilaian subyektif dilakukan secara kualitatif oleh pasien atau dokter. Penilaian semikuantitatif untuk menilai jaringan parut telah dikembangkan dengan menggunakan skala untuk membuat penilaian subyektif menjadi lebih obyektif. ${ }^{16}$ Vancouver scar score (VSS) pertama kali dijabarkan oleh Sulivan pada tahun 1990 dan dimodifikasi oleh Baryza pada tahun 1995. Skala ini menilai 4 variabel yaitu vaskularisasi, ketinggian/ketebalan, konsistensi dan pigmentasi ${ }^{16-18}$ dengan rincian sebgai berikut: konsistensi (0-5 poin), ketebalan (0-3 poin), vaskularisasi (0-3 poin), dan pigmentasi (0-3 poin). ${ }^{2}$

Penelitian ini dilakukan pada 17 luka operasi dengan jenis operasi yang dikategorikan operasi dengan luka bersih. Insisi awal $1 / 2$ dari panjang insisi luka dilakukan dengan pisau bedah dan sisanya diperpanjang dengan pisau elektrokauter. Jaringan parut yang terbentuk dinilai dengan menggunakan VSS saat 3 bulan setelah operasi.

Pada penelitian ini, hasil uji perbedaan kedua perlakuan dengan uji Wilcoxon signed ranks menunjukkan tidak terdapat perbedaan bermakna antara hasil VSS kelompok A dan B $(P>0,05)$. Hasil penelitian ini sejalan dengan beberapa penelitian sebelumnya baik yang berdasarkan jenis operasi, ${ }^{19}$ kejadian infeksi, ${ }^{20}$ dan keamanannya. ${ }^{6}$ Hal ini sesuai dengan teori yang menerangkan tentang cara kerja elektrokauter yaitu ujung elektrokauter menghasilkan panas yang menyebabkan terjadi hemostasis dan perubahan dari protein yang menghasilkan koagulasi jaringan. Elektrokauter menghasilkan panas sebagai hasil induksi dari sumber listriknya, yang dihantarkan melalui konduksi dari instrumen langsung ke jaringan. Pengaturan amplitudo harus cukup tinggi untuk menghasilkan koagulasi, namun tidak terlalu tinggi sehingga tidak menyebabkan cedera luka bakar pada jaringan di luar lapang operasi. $^{21}$ Prosedur bedah listrik menggunakan arus listrik bolak-balik yang akan meningkatkan suhu intrasel dengan tujuan untuk menghasilkan evaporasi, dehidrasi jaringan, dan koagulasi protein. Efek yang dihasilkan ini berfungsi untuk memotong jaringan, koagulasi jaringan, menghentikan perdarahan (hemostasis), dan menghancurkan jaringan seperti jaringan tumor. $^{22}$ 


\section{SIMPULAN}

Berdasarkan hasil penelitian ini dapat disimpulkan bahwa tidak terdapat perbedaan dalam penyembuhan dari kedua bagian luka insisi yang menggunakan pisau bedah dan pisau elektrokauter pada operasi dengan luka bersih. Dengan kata lain, insisi menggunakan pisau bedah dan pisau elektrokauter menghasilkan bekas luka operasi yang sama kualitasnya dinilai dengan Vancouver Scar Score.

\section{DAFTAR PUSTAKA}

1. Verhaegen PDHM, van der Wal MBA, Middelkoop E, van Zuijlen PPM. Objective scar assessment tools: A clinimetric appraisal. Plast Reconstr Surg. 2011;127(4):1561-70.

2. Kaartinen I. Assessment of skin scars in clinical practice and scientific studies. Departement of Plastic Surgery, Musculoskeletal Surgery and Rehabilitation. University of Tampere. Finland: Coronet Books, 2011.

3. Vujevich JJ, Goldberg LH. Cryosurgery and electrosurgery. In: Goldsmith LA, Katz SI, Gilchrest BA, Paller AS, Leffell DJ, Wollf K, editors. Fitzpatrick's Dermatology in General Medicine (8th ed). New York: McGraw Hill, 2012; p. 2972-6.

4. Soon SL, Washington CV. Electrosurgery, electrocoagulation, electrofulguration, electrodessication, electrosection, electrocautery. In: Robinson JK, Hanke CW, Siegel DM, Fratila A, editors. Surgery of the Skin: Procedural Dermatology (2nd ed). Philadelphia: Elsevier, 2010; p. 137-51.

5. Sbano E, Sbano P. Electrosurgery. In: Rusciani L, Robins P, editors. Textbook of Dermatologic Surgery. Italy: Piccin Nuova Libraria, 2008; p. 505-17.

6. Shah KRP, Khanal GP, Chaudhary P, Rijal R, Maharjan R, Paneru Sr, Pokharel B. Safety and efficacy of electrocautery in comparison to scalpel in forearm skin incision during fixation of fracture of forearm bone with plate and screws. International Journal of Chemical and Biomedical Science. 2015;1(2):52-5.

7. Chrysos E, Athanasakis E, Antonakakis S, Xynos E, Zoras O. A prospective study comparing diathermy and scalpel incisions in tension-free inguinal hernioplasty. Am Surg. 2005;71(4):3269.

8. Byrne FJ, Kearns SR, Mulhall KJ, McCAbe JP, Kaar K, Gilmore M, et al. Diathermy versus scalpel incisions for hemiarthroplasty for hip fracture: A randomized prospective trial. Eur J Orthop Surg Traumatol. 2007;17(5): 445-8.

9. Shamim M. Diathermy vs. scalpel skin incisions in general surgery: doubleblind, randomized, clinical trial. World J Surg. 2009;33(8):1594-9.

10. Chalya PL, Mchembe MD, Mabula JB, Gilyoma JM. Diathermy versus scalpel incision in elective midline laparotomy: a prospective randomized controlled clinical study. East Cent Afr J Surg. 2013;18(1):71-3.

11. Gauglitz GG, Korting HC, Pavicic T, Ruzicka T, Jeschke MG. Hypertrophic scarring and keloids: Pathomechanisms and current and emerging treatment strategies. Mol Med. 2011;17(1-2):11325.

12. Sherratt JA, Maini PK. Mathematical modelling of scar tissue formation. Posstdoctoral research assisstant. Engineering and Physical Sciences research Council. Jun 1996-May 1999. Edinburgh: Departement of Mathematics, Heriot-Watt University.

13. Kraft J, Lynde C. Giving burns the first, second and third degree-classification of burns. 2012. Available from: www.skincareguide.ca

14. Burrows NP, Lovell CR. Keloid and hypertrophic scars. In: Burns $\mathrm{T}$, Breathach S, Cox N, Griffiths C, editors. Rook's Textbook of Dermatology (7th ed). USA: Blackwell Publishing, 2004; p.54-6.

15. Edriss AS. Management of keloid and hypertrophic scars. Ann Burns Fire Disasters. 2005;18(4):1-14.

16. Fearmonti R, Bond J, Erdmann D, Levinson HA. Review of scar scales and scar measuring devices. Eplasty. 2010;10:354-63.

17. Bayat A, McGrouther DA, Ferguson MW. Skin scarring. BMJ. 2003;326:88-92.

18. Brusselaers N, Pirayesh A, Hoeksema H, Verbelen J, Blot S, Monstrey S. Burn scar assessment: a systematic review of 
different scar scales. J Surgical Res. 2010;164:e115-e123.

19. Kearns SR, Connolly EJ, McNally S, McNamara Da, Deasy J. Randomized clinical trial of diathermy versus scalpel incision in elective midline laparotomy. Br J Surg. 2001;88(1):41-4.

20. Groot G, Chappell EW. Electrocautery used to create incisions does not increase wound infection rates. Am J Surg. 1994;167(6):601-3.
21. Townsend C, Beauchamp RD, Evers BM, Mattox K. Principles of preoperative and operative surgery Sabiston Textbook of Surgery (19th ed). eBook ISBN 9781455738083. Elsevier, 2012.

22. Munro MG. Fundamentals of Electrosurgery part I: Principle of radiofrequency energy for surgery. 2012. The SAGES Manual on the Fundamental Use of Surgical Energy (FUSE) 2012; p. 1559. 